Malaviya, A. N., Sama, S. K., Ramachandran, K., Gandhi, P. C., and Tandon, B. N. (1971). American fournal of Tropical Medicine and Hygiene, 20, 502.

Maynard, E. P., Sadikali, F., Anthony, P. P., and Barker, L. F. (1970) Lancet, $2,1326$.

Mirick, G. A., and Shank, R. E. (1959). Transactions of the American Clinical and Climatological Association, 71, 176.

Morrow, R. H., jun., Smetana, H. F., Sai, F. T., and Edgcomb, J. H. (1968). Annals of Internal Medicine, 68, 1250 .

Morrow, R. H., jun., Sai, F. T., Edgcomb, J. H., and Smetana, H. F. (1969). Transactions of the Royal Society of Tropical Medicine and Hygiene, 63, 755.

Mosley, J. W., Barker, L. F., Shulman, N. R., and Hatch, M. H. (1970). Nature, 225, 953.

Nefzger, M. D., and Chalmers, T. C. (1963). American fournal of Medicine,

35, 299.
Ogunlesi, T. O. (1962). Paper read at Conference of Association of Physicians of West Africa, University College Hospital, Ibadan, Nigeria, November 1962.
Payet, M., Camain, R., Pene, P., Moalainer, M., and Sankale, M. (1962). Paper read at Conference of Association of Physicians of West Africa, University College Hospital, Ibadan, Nigeria.

Prince, A. M. (1970). American fournal of Tropical Medicine and Hygiene, 19,872 . Ringentz, O., and Zetterberg, B. (1967). New England Fournal of Medicine,
276, 540.

Shulman, N. R., and Barker, L. F. (1969). Science, 165, 304.

Shulman, N. R., Hirschman, R. J., and Barker, L. F. (1970). Annals of Internal Medicine, 72, 257.

Smetana, H. F. (1957). In Hepatitis Frontiers, Henry Ford Hospital International Symposium, ed. F. W. Hartman, G. A. Lo Grippo, J. G. national Symposium, ed. F. W. Hartman, G. A.

Viswanathan, R. (1957). In Hepatitis Frontiers, Henry Ford Hospital International Symposium, ed. F. W. Hartman, G. A. Lo Grippo, International Symposium, ed. F. W. Hartman, G. A. Lo Grippo, J. G. Mateer, and J. Barrow, p. 207. Boston, Little, Brown.

Vogel, C. L., Mody, N., Anthony, P. P., and Barker, L. F. (1970). Lancet, 2,621

Vyas, G. N., and Shulman, N. R. (1970). Science, 170, 332.

Wright, R., McCollum, R. W., and Klatskin, G. (1969). Lancet, 2, 117.

\title{
Effect of Hormonal Therapy on Plasma Testosterone Levels in Prostatic Carcinoma
}



British Medical fournal, 1971, 4, 391-394

\section{Summary}

Plasma concentrations of testosterone were estimated in normal men, in patients before treatment for prostatic cancer, and in patients who had had various forms of endocrine treatment for prostatic carcinoma. There was no decline in plasma testosterone levels with age. Patients with non-metastatic disease had levels similar to those of normal controls, but in advanced metastatic disease the levels were low. After orchidectomy the plasma testosterone level fell to that found in normal women. In every patient stilboestrol in doses as small as $1 \mathrm{mg}$ three times a day suppressed plasma testosterone at first to negligible amounts, irrespective of the clinical response. Subsequently a small but significant rise in the concentration was always observed over a period of six months' oestrogen therapy. Pituitary ablation with yttrium-90 lowered the plasma testosterone concentration again to negligible amounts in patients who had been on stilboestrol. In advanced metastatic disease this was often associated with relief of pain. Preliminary studies with aminoglutethimide indicate that it can produce biochemical and clinical effects similar to those of pituitary ablation.

\section{Introduction}

Our purpose was to study the effect on plasma testosterone levels of the various forms of endocrine therapy for prostatic carcinoma. We therefore measured concentrations of plasma testosterone before and during treatment and compared them with those in normal men. The treatments included stilboestrol, orchidectomy, pituitary ablation, and "medical adrenalectomy"

Institute of Urology, London WC28 $8 \mathrm{JE}$

M. R. G. ROBINSON, F.R.C.S., Research Fellow

Department of Clinical Endocrinology, Imperial Cancer Research Fund, London WC2A 3PX

B. S. THOMAS, PH.D., M.I.BIOL., Senior Technical Officer with aminoglutethimide combined with oestrogen therapy. Surgical adrenalectomy was considered unsuitable for elderly patients with advanced disease.

The plasma testosterone was measured by the method of Thomas (1971). Concentrations of testosterone as low as $10 \mathrm{ng} / 100 \mathrm{ml}$ plasma can be measured by this test.

\section{Patients and Methods}

Forty-five patients with carcinoma of the prostate were studied before and during hormonal therapy, and 25 men without evidence of the disease and in good general health were used as controls.

The 45 patients had an examination of the prostate under general anaesthesia, cystoscopy, intravenous pyelography, chest $x$-ray examination, skeletal surveys by radiography and strontium-90 scintigraphy, and serum acid phosphatase measurements. In each case the diagnosis of prostatic carcinoma was confirmed by histological examination of biopsy specimens taken with a Vim-Silverman needle or by cytological examination of material aspirated by a Franzen needle (Williams et al., 1967). Because of the diurnal variation in the concentration of plasma testosterone (Saxena and Gandy, 1970), blood for testosterone assay was taken only between 9 and 11 a.m. Results from specimens taken on the day of admission to hospital or on the day of any surgical procedure were disregarded, since anxiety is often associated with a raised testosterone level.

\section{Results}

The patients with prostatic cancer were divided into those without metastases (age range 51-80 years, mean 69) and those with metastases (age range 52-78 years, mean 64). The plasma testosterone levels in the patients in each group are expressed as the mean of three assays made on three consecutive days. The age range of the men in the control group was 20-78 years, and in their case only single assays were made.

Fig. 1 relates plasma testosterone concentrations to age in the controls and in untreated cases of carcinoma of the prostate. Fig. 2 compares the testosterone levels in controls aged under 


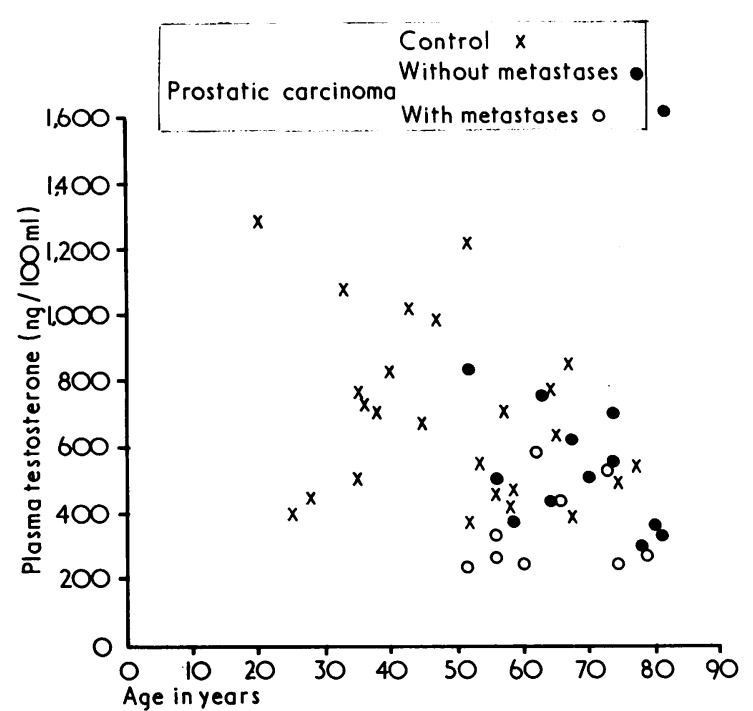

FIG. 1-Relationship between plasma testosterone levels and age in the controls and in untreated patients with carcinoma of prostate.

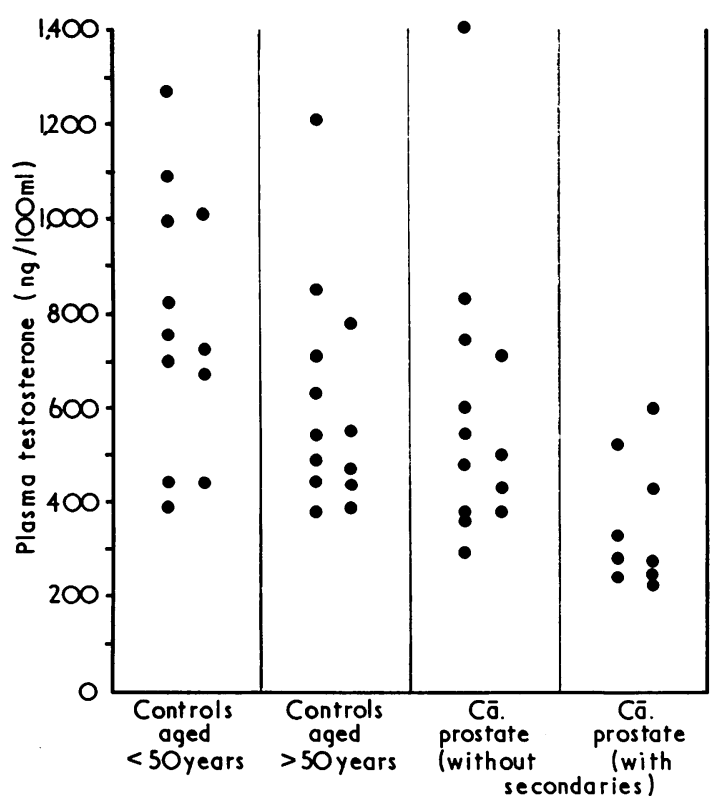

FIG. 2-Plasma testosterone levels in controls aged under 50 , controls aged 50 or over, and untreated patients with or without metastases.

50-that is, below the common prostatic cancer age-controls aged 50 or over, untreated patients without metastases, and untreated patients with metastases. The plasma testosterone levels did not decline with age in the controls (Table I), and there is no significant difference in the results for normal men aged under 50 or aged 50 and over $(t=1 \cdot 65, P>0 \cdot 1)$. There is also no significant difference between the mean level in men aged 50 or over in the control group and the mean level in patients with prostatic cancer with no evidence of metastases $(t=0.04, P>0.1)$. However, the mean testosterone level in patients with metastatic disease was significantly lower than that of the appropriate controls $(t=2.96, \mathrm{P}=0.01)$.

TABLE I-Plasma Testosterone Levels (ng/100 ml)

\begin{tabular}{l|c|c|c|c}
\hline & \multicolumn{2}{|c|}{ Controls } & \multicolumn{2}{c}{ Carcinoma of Prostate } \\
\cline { 2 - 5 } & $<50$ Years & $\geqslant 50$ Years & Without Secondaries & With Secondaries \\
\hline No. & 12 & 13 & 13 & 69 \\
$\overline{\mathbf{x}}$ & 775 & 607 & 603 & 364 \\
S.D. & \pm 267 & \pm 235 & \pm 347 & \pm 135 \\
\hline
\end{tabular}

\section{EFFECTS OF ENDOCRINE THERAPY}

The plasma testosterone levels in patients who were treated by various types of endocrine therapy are shown in Fig. 3. The results are summarized in Table II.

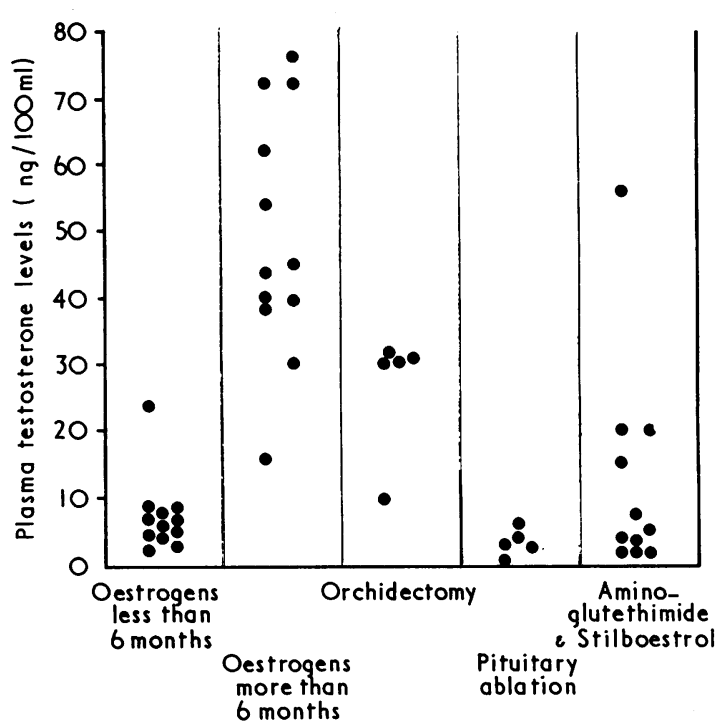

FIG. 3-Plasma testosterone levels in treated patients.

TABLE II-Mean Plasma Testosterone Levels (ng/100ml)

\begin{tabular}{|c|c|c|c|c|c|}
\hline & \multicolumn{2}{|c|}{ Stilboestrol } & \multirow{2}{*}{$\begin{array}{l}\text { Stilboestrol } \\
\text { plus A.G. }\end{array}$} & \multirow{2}{*}{ Orchidectomy } & \multirow{2}{*}{${ }^{\circ 0} \mathbf{Y}$} \\
\hline & $<6$ months & $>6$ months & & & \\
\hline $\begin{array}{l}\text { No. } \\
\overline{\mathbf{x}} \\
\text { S.D. }\end{array}$ & $\begin{array}{l}12 \\
<10 \\
\end{array}$ & $\begin{array}{r}12 \\
46.4 \\
\pm 18.5\end{array}$ & $\begin{array}{l}11 \\
10\end{array}$ & $\begin{array}{c}5 \\
32.8 \\
\pm 3.6\end{array}$ & $\begin{array}{r}5 \\
<10 \\
\end{array}$ \\
\hline
\end{tabular}

Irrespective of the dose of stilboestrol (range 1-100 $\mathrm{mg}$ three times a day), the plasma testosterone concentrations with one exception fell to undetectable amounts-that is, to less than $10 \mathrm{ng} / 100 \mathrm{ml}$ plasma (Fig. 3). This occurred in every patient whether their clinical response to treatment was good or not. Fig. 4 relates oestrogen dosage to the number of days taken for

Stilboestrol

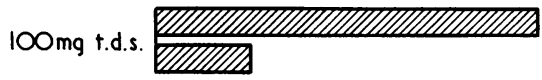

$25 \mathrm{mg}$ t.d.s. WIIIIIIIIIIIIA

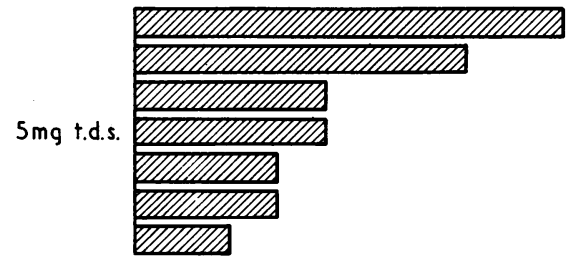

$1 \mathrm{mg}$ t.d.s.

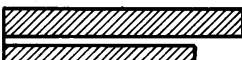

\begin{tabular}{lllllllllll}
\hline & 1 & 2 & 3 & 4 & 5 & 6 & 7 & 8 & 9 & 10
\end{tabular}

No of days for plasma testosterone to fall
to less thon IOng/iOOml

FIG. 4-Number of days on stilboestrol therapy in various doses before plasma testosterone level fell to less than $10 \mathrm{ng} / 100 \mathrm{ml}$. 
the plasma testosterone to fall below $10 \mathrm{ng} / 100 \mathrm{ml}$. Stilboestrol $1 \mathrm{mg}$ three times a day was as effective as $100 \mathrm{mg}$ three times a day.

After two to six months the plasma testosterone concentrations rose without exception to between 30 and $80 \mathrm{ng} / 100 \mathrm{ml}$. Fig. 5 shows the response in a typical case to stilboestrol $5 \mathrm{mg}$ three times a day. In none of five cases studied at monthly

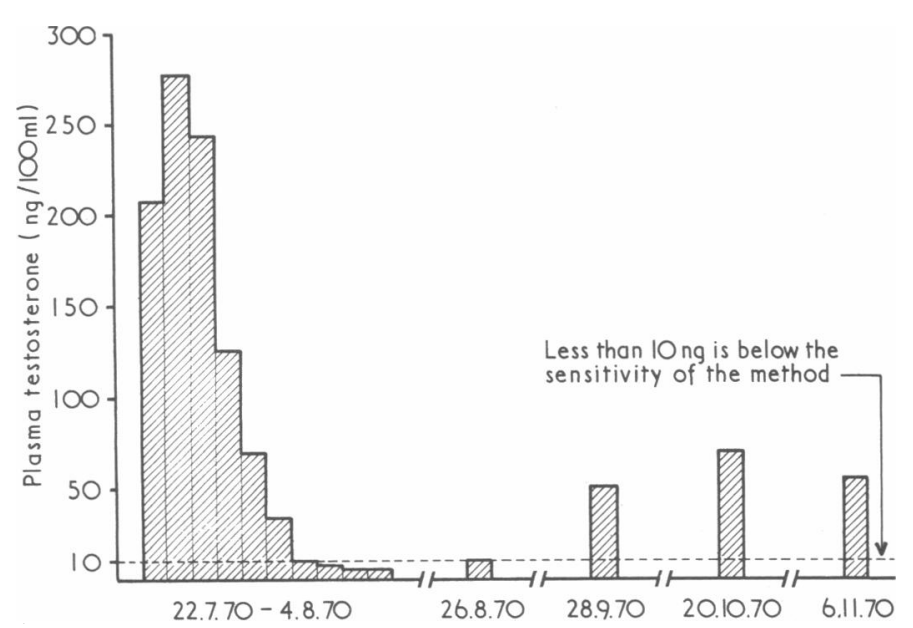

FIG. 5-Plasma testosterone levels over a period of four months in a patient on stilboestrol $5 \mathrm{mg}$ three times a day.

intervals had the plasma testosterone risen before two months, but in all it had risen to the range $30-80 \mathrm{ng} / 100 \mathrm{ml}$ by six months. All plasma testosterone concentrations in patients taking stilboestrol for more than six months were in this same range. The difference in the levels in patients treated for less than six months and those treated for more than six months is significant $(t=8.05, \mathrm{P}<0.01)$.

In the small series of cases treated by orchidectomy the plasma testosterone levels fell to the region of only $30 \mathrm{ng} / 100 \mathrm{ml}$ - similar to those found in normal women.

Pituitary ablation with yttrium-90 was perfomed as a palliative measure on five patients with painful bone metastases (Kelly et al., 1951; Fergusson and Phillips, 1962). All had previously received stilboestrol for more than a year. Their plasma testosterone levels were in the range of $30-80 \mathrm{ng} / 100 \mathrm{ml}$. Within five days of operation these levels had fallen in each case to below $10 \mathrm{ng} / 100 \mathrm{ml}$ (Fig. 6) and in all cases this was associated with relief from pain.

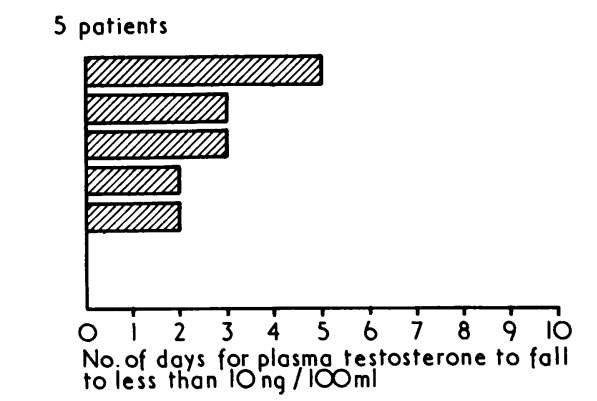

FIG. 6-Number of days taken for plasma testosterone to fall to less than $10 \mathrm{ng} / 100 \mathrm{ml}$ after pituitary ablation.

Aminoglutethimide with oestrogen treatment relieved pain in 4 out of 11 cases, and in all four the plasma testosterone fell to below $10 \mathrm{ng} / 100 \mathrm{ml}$. Of the unresponsive patients three showed a similar fall in plasma testosterone.

In four patients with painful bone metastases not previously treated doses of stilboestrol ranging from 1 to $100 \mathrm{mg}$ three times a day were equally effective in rapidly relieving symptoms. In all four cases the plasma testosterone fell to insignificant levels within 10 days (Table III).

TABLE III-Response of Painful Metastases to Different Doses of Stilboestrol in Four Cases of Prostatic Cancer

\begin{tabular}{c|c|c}
\hline Dose of Stilboestrol & $\begin{array}{c}\text { No. of Days for P.T. to Fall } \\
\text { to }<10 \mathrm{ng}\end{array}$ & $\begin{array}{c}\text { No. of Days for } \\
\text { Relief of Pain }\end{array}$ \\
\hline $100 \mathrm{mg}$ t.d.s. & 4 & 7 \\
$15 \mathrm{mg}$ t.d.s. & 4 & 3 \\
$5 \mathrm{mg}$ t.d.s. & 5 & 4 \\
$1 \mathrm{mg}$ t.d.s. & 5 & 4 \\
\hline
\end{tabular}

\section{Discussion}

There was no significant decline in plasma testosterone levels with age in our control group of normal men. This agrees with the findings of Kent and Acone (1966). Southren et al. (1968) attributed it to a reduced metabolic clearance rate running parallel with the fall in production rate which occurs after the second decade.

Similarly, the overall plasma testosterone levels in men with prostatic cancer are not significantly different from those of normal men aged 50 or over. The significantly lower levels in patients with advanced metastatic disease probably reflect the general debility of this group and may have no relation to the endocrinology of the disease. Young and Kent (1968), reporting similar findings, observed that low plasma testosterone concentrations were also a feature of other advanced malignant conditions and chronic illness.

The rapid fall in plasma testosterone to negligible amounts after small doses of stilboestrol suggests that even $1 \mathrm{mg}$ three times a day is enough to block the release of luteinizing hormone by the pituitary-hypothalamic axis. Our results show a much greater decrease in plasma testosterone than was observed by Alder et al. (1968) in seven patients taking stilboestrol $90 \mathrm{mg}$ daily. Since the fall occurred in all our cases except one, whatever the clinical response, a failure of a prostatic carcinoma to respond initially to oestrogen treatment must mean that the tumour has not been, or is no longer, androgen-dependent.

The fact that the fall in our cases was even greater than that seen after orchidectomy suggests that stilboestrol may also directly inhibit the production of androgens by the adrenal cortex. The small but significant rise after a few months' treatment may result partly from renewed adrenal cortical activity and partly from increased testosterone binding by plasma proteins induced by oestrogen administration (Kato and Horton, 1968). Forchielli et al. (1965) observed that the administration of $1 \mathrm{mg}$ of ethinyloestradiol daily decreased the urinary plasma testosterone excretion from $63 \mu \mathrm{g}$ (S.D. $\pm 1 \cdot 1$ ) in 24 hours to $8 \mu \mathrm{g}$ (S.D. \pm 0.3 ), while the plasma level fell only from $840 \mathrm{ng} / 100 \mathrm{ml}$ (S.D. \pm 70 ) to $100 \mathrm{ng} / 100 \mathrm{ml}$ (S.D. \pm 40 ). This again suggests an increase in plasma testosterone binding by plasma proteins associated with a fall in metabolic clearance rate. Such bound testosterone is not free to undergo catabolism and exert androgenic effects (Farnsworth, 1970).

The increase in plasma testosterone over six months' oestrogen therapy may be compared with the increase in 17-oxosteroids, 17-ketogenic steroids, and oestrogens to pretreatment levels in patients on prolonged stilboestrol therapy reported by Bulbrook et al. (1959). They associated the increase with renewed tumour activity. The relief of symptoms associated with a further fall of plasma testosterone to negligible levels seen after pituitary ablation in patients with painful metastases suggests that at least some of the plasma testosterone remaining in patients on stilboestrol is available to stimulate those tumours which have remained hormone-dependent.

Aminoglutethimide inhibits the conversion of cholesterol to 5-pregnenolone by blockage of the $\mathrm{C} 22$ position of the steroid 
side chain (Cash et al., 1969; Hughes and Burley, 1970), thus preventing production of aldosterone, corticosteroids, and adrenal androgens. It has been reported, however, that it does not inhibit production of testicular androgens (Gaunt et al., 1968). Treatment must therefore be continued indefinitely and supplemented with corticosteroids and stilboestrol. Aminoglutethimide is now being tried in the treatment of metastatic cancer of the prostate (Fergusson and Robinson, unpublished data), and in every case we have observed a substantial fall in plasma testosterone before giving supplementary corticosteroid therapy.

There is ample evidence from both animal and tissue culture experiments that oestrogens directly inhibit prostatic gland function and its metabolism of testosterone (Huggins and Clark, 1940; Goodwin et al., 1961; Farnsworth, 1969; Belitsky et al., 1970). This may explain why most cases of prostatic cancer remain well controlled even when there is a small increase in plasma testosterone concentrations over six months. It would be of clinical interest to know if the small doses of stilboestrol that suppress testosterone production via the testicular-pituitary feedback mechanism are sufficient to exert the maximum effect on the malignant cells within the gland. This would seem to be particularly important in view of the risk of cardiovascular complications associated with prolonged administration of high doses of oestrogens.

We thank Mr. J. D. Fergusson, director of teaching and research at the Institute of Urology, and Dr. R. D. Bulbrook, director of the department of clinical endocrinology, Imperial Cancer Research Fund, for their helpful advice. We are indebted to the department of medical art at the Institute of Urology for the charts. One of us (M.R.G.R.) received a grant from the St. Peter's Research Trust.

\section{References}

Alder, A., et al. (1968). British Medical fournal, 1, 28.

Belitsky, P., Elhilali, M. M., and Oliver, J. A. (1970). fournal of Urology, 104,453 .

Bulbrook, R. D., Franks, L. M., and Greenwood, F. C. (1959). Acta Endocrinologica, 31, 481.

Cash, R., Petrini, M. A., and Brough, A. J. (1969). Fournal of the American Medical Association, 208, 1499.

Farnsworth, W. E. (1969). Investigative Urology, 6, 423.

Farnworth, W. E. (1970). Some Aspects of the Aetiology and Biochemistry of Prostatic Cancer, ed. K. Griffiths and G. G. Pierrepoint, p. 3. Cardiff, Alpha Omega.

Fergusson, J. D., and Phillips, D. E. H. (1962). British fournal of Urology,

Forchielli, E., et al. (1965). Acta Endocrinologica, 50, 51.

Gaunt, R., Steinetz, B. G., and Chart, T. Y. (1968). Clinical Pharmacology and Therapeutics, $9,657$.

Goodwin, D. A., Rasmussen-Taxdal, D. S., Ferreira, A. A., and Scott, W. W. (1961). Fournal of Urology, 86, 134.

Huggins, C., and Clark, P. J. (1940). Fournal of Experimental Medicine,

Hughes, S. W. M., and Burley, D. M. (1970). Postgraduate Medical fournal, 46, 409.

Kato, T., and Horton, B. (1968). Fournal of Clinical Endocrinology, 28, 1160.

Kelly, K. H., et al. (195i). Fournal of the National Cancer Institute, 11, 967.

Kent, J. R., and Acone, B. (1966). Excerpta Medica International Congress Series, No. 101, p. 31. Amsterdam, Excerpta Medica Foundation.

Saxena, B. B., and Gandy, H. M. (1970). In Symposium on In Vitro Procedures with Radio Isotopes in Clinical Medicine and Research. Vienna, International Atomic Energy Agency.

Southren, A. L., Gordon, G. G., and Tochimotos. (1968). Fournal of Clinical Endocrinology, 28, 1105.

Thomas, B. (1971). Journal of Chromatography, 56, 37.

Williams, J. P., Still, B. M., and Pugh, R. C. B. (1967). British fournal of Urology, 39, 549 .

Young, H. H., and Kent, J. R. (1968). fournal of Urology, 99, 788.

\title{
Prevention of Early Postoperative Deep Vein Thrombosis by Intermittent Compression of the Leg during Surgery
}

\author{
S. SABRI, V. C. ROBERTS, L. T. COTTON
}

British Medical fournal, 1971, 4, 394-396

\section{Summary}

A clinical trial is described in which the effect of intermittent compression of the lower limb during surgery on the incidence of early postoperative deep vein thrombosis was assessed. Deep vein thromboses were diagnosed by the 125 Ifibrinogen uptake test. Peroperative intermittent compression was achieved by means of an inflatable plastic splint coupled to a pneumatic controller. By compressing only one leg of each patient, each patient acted as his own control.

With a sequential statistical analysis, 39 patients were required to pass the $5 \%$ level of significance. Eleven thrombi were detected in the control (uncompressed) legs and two occurred in the compressed legs; one of the latter was bilateral. The investigation shows that increasing the pulsatility of the venous flow in the leg is a potent prophylactic against postoperative deep vein thrombosis. Department of
Medical School, London S.E.5

S. SABRI, M.B., B.CH., PH.D., Honorary Senior Surgical Registrar/Lec-

v. C. ROBERTS, PH.D., M.I.E.E., Honorary Lecturer in Biomedical Engineering.

L. T. COTTON, M.CH., F.R.C.s., Consultant Surgeon and Director of the Department
Introduction

Passive exercise of one leg during surgery has been shown to reduce the incidence of early deep vein thrombosis in that leg compared with the other (control) leg by $77 \%$, as judged by the 125I-fibrinogen test (Sabri et al., 1971). Passive exercise was achieved by means of a motorized foot mover which produced continuous dorsal and plantar flexion of one foot at a rate of 50 cycles per minute and with an amplitude of $\pm 20^{\circ}$ about the vertical. At this rate and amplitude pedalling increases both the mean flow of blood in the femoral vein and its pulsatility. The mean flow is increased by $35 \%$, the peak flow by almost $60 \%$, and the pulsatility of the flow is increased fivefold (Roberts et al., 1971a).

The question now to be answered is which factor is the more effective in reducing deep vein thrombosis during surgery, increasing the mean flow of venous blood in the legs or increasing its pulsatility? We have found that the most effective means of increasing the pulsatility of venous blood flow is the application of a train of equispaced compressive impulses to the leg, produced by surrounding it with an inflatable plastic bag coupled to a special pneumatic regulator (Roberts et al., 1971b). By this method pulsatility is increased without a concomitant rise in the mean venous flow. Furthermore, this investigation has shown that intermittent compression of one leg does not lead to any significant change in the pattern of flow in the other leg. A clinical trial has been designed to evaluate the effect of increasing the pulsatility of 